\title{
Historical Development of Secondary Education in Bangladesh: Colonial Period to 21st Century
}

\author{
Md. Mustafizur Rahman (Corresponding Author) \\ Faculty of Education, Universiti Kebangsaan Malaysia (UKM) \\ 43600, Bangi, Selangor, Malaysia
}

Tel: 60-16-639-3102Ｅ-mail: mustafiz236@yahoo.com

Dr. Mohd Izham Mohd Hamzah

Faculty of Education, Universiti Kebangsaan Malaysia (UKM)

Tel: 60-3-8921-6362; 60-12-731-4529; Fax: 60-3-8925-4372 E-mail: izham@ukm.my

Professor Datuk Dr. T. Subahan Mohd Meerah

Faculty of Education, Universiti Kebangsaan Malaysia (UKM)

Tel: 60-3-892-16284; 60-13-397-6739; Fax: 60-3-8925-4372Ｅ-mail: subhan@ukm.my

\section{Mizan Rahman}

Faculty of Business \& Law, University of Lincoln, Brayford, UK

Tel: 44 -15-2288-6345Ｅ-mail: mrahman@lincoln.ac.uk

\begin{abstract}
In a world of global market competition, the secondary level education has become a part of basic education. Secondary schools are vested with the responsibility of imparting knowledge, skills and attitudes essential for individuals to fit into society and be able to contribute fruitfully to its development. This article analyses the development of secondary education in Bangladesh in different period of time, socio-political context. Therefore, a general overview of secondary education is provided which is followed by historical evolution of secondary education in the British and Pakistani rule over Bangladesh. In conjunction with primary and mass education, secondary education was revised with great emphasis on the development of an all-round individual, female education, the acquisition of quality education, and the inculcation of technical and science education. A good number of commissions and committee were formed in different time to make changes in educational arena. Following the recommendations, the system of educational administration has been decentralised to promote school-based management and teacher empowerment. Furthermore, the non-government schools have been always encouraged to play an active role in providing secondary level education. A new education policy for Bangladesh has been tabled in September, 2009 after restoration of democratic process. At secondary education level a broad-based change in educational objectives, structure and system, curriculum have been proposed which is under public scrutiny.
\end{abstract}

Keywords: Secondary education, colonial education, Wood's Educational Despatch, Qudrat-e-Khuda education Commission 1974, Moniruzzaman Miah Education Commission 2003, New education policy 2009

\section{Introduction}

Formal education is a fulcrum of sustainable development. Education allows individuals to develop within their community and country, and allows nations to compete and survive in the global economy. Education plays a critical role in fostering basic intellectual abilities, expanding further educational opportunities that are vital to success in a world where power is closely linked with knowledge. Quantitative and qualitative access to knowledge is key to skills formation and paramount to improving productivity. Therefore, education, which stimulates and empowers people to participate in their own development, has proved to be the most important instrument for poverty reduction in Bangladesh. Education is also heralded to reduce population growth, reduce maternal mortality, increase agricultural productivity, higher labor force participation and lead to democratization (Case, 2006; McGrath, 1999). Investment in education results in a citizenry that is more committed to good governance, fiscal accountability and transparency.

Bangladesh is one of the least developed countries of the world today. It is plagued with multifarious problems encompassing its social, political, and economical structures. The three and half decades since the country gained 
independence have been traumatic. Recurring political upheavals, natural disasters, dramatic social changes and economic convulsions contributed to the gloomy nature of the life of the common man. The bulk of the people live in abject poverty either in the run-down rural areas or in destitute urban slums. Only fortunate few in the cities and towns have access to whatever goods and services are provided by the government. Therefore, in Bangladesh, poverty eradication is currently at the top of government agendas. The Constitution of the People's Republic of Bangladesh enjoins upon the Government of Bangladesh the obligation to ensure literacy of all the citizens (GoB, 1972). The Government of Bangladesh has made commitments in the World Education Forum (UNESCO, 2000) towards achievement of 'Education for All' goals and targets for every citizen by the year 2015. Pursuant to its constitutional obligations and international commitments, the government is determined to ensure 'Education for All' in the shortest possible time. Active measures are taken for accelerating primary education program in the light of global awareness in the education sector as well as Bangladesh's national goals. However, in a world of global market competition, the secondary level education has also become a part of basic education that should be universally available (Mulford, 2002). Secondary schools are vested with the responsibility of imparting knowledge, skills and attitudes essential for individuals to fit into society and be able to contribute fruitfully to its development. A high school graduate in Bangladesh can expect to earn 200 percent over those with no education (Ilon, 2000). Therefore, Bangladesh hopes to gain from secondary education system more effective citizens who can be productive participants, domestically and abroad, in markets and communities.

\section{The Structure of the Education System in Bangladesh}

Education in Bangladesh has three major stages - primary, secondary and higher education. Primary education is a 5 -year cycle while secondary education is a 7-year one with three sub-cycles: 3 years of junior secondary, 2 years of secondary and 2 years of higher secondary. The entry age for primary is 6 years. The junior secondary, secondary and higher secondary stages are designed for age groups 11-13, 14-15 and 16-17 years. Higher secondary is followed by higher education in general, technical, technology and medical streams requiring 5-6 years to obtain a Master's degree.

\subsection{Streams of the Education System}

Bangladesh's present system of education is more or less a legacy from the British (Ali, 1986). It is characterised by co-existence of three separate streams running parallel to each other. The mainstream happens to be a vernacular based secular education system carried over from the colonial past. There also exists a separate religious system of education. Finally, based on use of English as the medium of instruction, another stream of education, modelled after the British education system, using the same curriculum, has rapidly grown in the metropolitan cities of Bangladesh. Primary level education is provided by two major institutional arrangements (stream): general and madrasah. Secondary education has three major streams: general, technical/ vocational and madrasah. Higher education, likewise, has 3 streams: general (inclusive of pure and applied science, arts, business and social science), madrasah and technology education. Technology education, in its turn, mainly includes agriculture, engineering, medical, textile, leather technology and ICT. Madrasah functioning parallel to the three major stages have similar core courses as in the general stream (Primary, Secondary and Postsecondary) but have special emphasis on religious studies. Therefore, at secondary and higher level however diverse the above streams may apparently look, they have certain common elements, and there exists scope for re-integration of graduates of one stream with the other at different levels. Figure 1 depicts different streams of the education system in Bangladesh. (Figure 1)

\subsection{Secondary Level Education Institutions in Bangladesh}

Post-primary education in the general stream is imparted by junior secondary schools (grade 6-8), secondary schools (grade 6-10) and higher secondary schools, known as Intermediate colleges (grade 11-12). Post primary level madrashas are known as Dakhil madrasha (grades 6-10), Alim madrasah (grades11-12). In terms of ownership and management of secondary schools, there are two major types; government secondary schools and non-government secondary schools (including Dakhil madrasahs). Nearly $98 \%$ of the post primary (secondary and higher secondary) institutions are owned and managed by private sector (BANBEIS, 2006). However, these institutions are private only in name because $100 \%$ of their salaries and wages, and the costs of their physical infrastructure development, durable educational supplies and equipment are provided by the government. Secondary education level institutions in technical and vocational stream include Polytechnics, VTI, Commercial Institutes, Technical Training Center, Textile Vocational Center, Agriculture Training Institute and others. Bangladesh Open University (BOU) also provides distance education for drop-out students at secondary education level with the support of a countrywide network of regional and local centres, radio and television programmes. The number of secondary level educational institutions (Post primary), teachers and pupils are presented in the Table1 below. (Table 1)

The total number of Government/Public school in 2009 is still 317. Different public secondary schools start serving students from grade 1,3,4, or 6, but all continue up to 10th grade. Among the existing 317 public schools, a few of them also started running 11 and 12 grades as a pilot basis from the year 2007. Table 2 shows the distribution of public secondary schools by region in Bangladesh. (Table 2) 
Government secondary schools are concentrated mostly in urban centers, resulting in a lack of educational access to the majority of children from rural areas, socio-economically backward families, girls from remote urban periphery areas and ethnic minorities. The public high schools are generally recognised as model schools in respect of their students' performance in the SSC examination (The Daily Star, 2008). The cost of education in these schools is just one third of any private school (The Daily Star, 2005). Therefore, low cost of education also draws a large number of admission seekers to the public secondary schools. Also it is tough to get chance to be admitted in public secondary schools in big cities. In January, 2008, a total of 36,532 students contested for 7,479 seats in the admission tests in Dhaka city's 24 government schools (New Age, 2008). Thus parents' interest, students' SES characteristics, administrative support from the government, teacher competency, and the resources of time, materials, facility have made public schools distinct. There are also some residential 'Cadet colleges' in Bangladesh, governed and run by the armed forces. These schools and colleges follow 'Bangladesh Textbook Board Curriculum' but use English as the medium of instruction.

Education in Bangladesh has faced both glory and travails throughout history. The present scenario of secondary education of Bangladesh is the result of evolution of educational practices in Indian sub-continent. In history, Bangladesh has experienced various educational systems which have left an indelible mark on Bangladeshi society. This article describes and analyses the evolution of secondary education in Bangladesh from the British period to $21 \mathrm{st}$ century.

\section{Educational Provision and Schools during Colonial Period}

Bangladesh is a new state in an ancient land. The territory constituting Bangladesh was under the Muslim rule for over five and a half centuries from 1201 to 1757 A.D. Subsequently, it came under the colonial rule of the British after defeat of the last sovereign ruler Nawab Sirajuddowala in 1757 (Islam, 1992). The British came in this subcontinent as merchants but ultimately they captured the political power and ruled over the entire Indian sub-continent including this territory for nearly 190 years from 1757-1947 (Mcleod, 2002). During that period Bangladesh was a part of the British Indian provinces of 'Bengal and Assam'. Education in Indian Sub-continent began from an indigenous educational system in ancient times, continued through an Islamic style of education in the medieval period as a result of Muslim invasions, and to imperialistic education delivered during British colonization. The East India Company and the British Crown were generally indifferent to education in Indian sub-continent until the early 19th century. Throughout the last decades of eighteen century and beginning of nineteenth century, European missionaries and the East India Company established several schools and colleges for developing educational programme of this area (Mukerji, 1957). Warren Hastings (1773-1744) the Governor General of the East India Company was sympathetic to Indian traditions and encouraged indigenous Indian thought to the exclusion of Western educational instruction (Mann, 2004). In 1781, 'Kolkatta Alia Madrasah', the first government college in the Indian sub-continent was set up to produce officials well versed in Islamic laws and in 1792 'Benaras Sangskrit College' was established by company officials (Chatterjee, 1976). But the colonial officials had differences of opinion among themselves regarding the purpose of educating the people of this subcontinent, about the medium of education, management of schools, the way of expanding educational facilities to the whole country (Ali, 1986; Mukerji, 1957; Viswanathan, 1989).

The East India Company first recognized their responsibility towards education in British India in the Charter Act of 1813 (clause 43) where they highlighted the need to promote and uplift oriental languages and literature as well as increase the knowledge of western sciences among the Indian population (Kumar, 1991). Thomas Macaulay (1800-1859), a member of the Governor General's Council, in his influential minute in 1835, articulated the supremacy of the Western culture, and English language; supported the education of the upper classes, and made a vigorous plea for spreading Western learning through the medium of English (Ghosh, 1993; Mukerji, 1957). Consequently in 1837, English was made the language of administration, and thus the East India Company officially entered into the education field of this sub-continent. As a result of the new policy there was a rapid growth in English schools and colleges (Mukerji, 1957; Seal, 1968) and English as the medium of instruction began to dominate the entire educational field (Ghosh, 1993; Roy, 1993). The indigenous educational institutions had to go through hard times due to financial crisis and the English domination (Chatterjee, 1976; Sinha, 1978). Most importantly, English became a compulsory subject in high schools, for matriculation and a requirement for university and college admissions (Mukerji, 1956). However, at the beginning of the nineteenth century a system of liberal English-language schools based on the British model was also instituted in the region that now constitutes Bangladesh (Ali, 1986; Nurullah \& Naik, 1962). Giving attention and importance to secondary education system and for its expansion, the British established 12 Zila schools and 3 collegiate schools (Public schools) in present Bangladesh land area during the years 1832-1855.

In this context, the celebrated Wood's Educational Despatch of 1854, resulting from an enquiry about education in India by the Select Committee of the British House of Commons, provided the legal foundation for modern public education in Bengal (Bhatt \& Aggarwal, 1969). Establishment of educational departments in every province, establishment of universities, supervision system, establishment of graded schools, grant-in-aid private schools, teachers' training institutions, creating a comprehensive secular system of education for the diffusion of practical knowledge using both 
English and the vernacular languages were the major outcomes of Wood's Despatch (Nurullah \& Naik, 1951). Secondary education as a distinct level of the total education structure emerged only after the publication of famous Education Despatch (Mominullah, 1984). However, one of the first documents advocating formal education for girls in Bangladesh (then part of India) is 'Wood's Education Despatch' of 1854. In that document, 'female education' was discussed and promoted because it enhanced the educational and moral tone of the people (Jalaluddin \& Chowdhury, 1997). What educational provision there was for girls focused on 'education for enlightened motherhood' (Chanana, 1994); they were being trained to be mothers, rather than, for example, being prepared for paid employment or for tertiary education. The universities of Calcutta, Madras and Bombay were established in 1857, which had a far reaching effect especially on the content, range and scope of secondary education. They dominated secondary schools in every respect and secondary education became a preparation for the university.

In 1882, Lord Ripon appointed the first Indian Education Commission with William Hunter as its Chairman (Nurullah $\&$ Naik, 1962). They suggested for leaving secondary education to private enterprise through a system of grants- in- aid, school-end 'Entrance examination' and appointment of trained teachers at secondary schools. After the all Indian Education Conference at Shimla in 1901, Lord Curzon published his education policy in the form of a government resolution in 1904 which contributed to the increase of vernacularisation at high school level especially in public schools, catered for the masses (Ali, 1986). But elite schools, European or convent schools used English as medium of instruction which excluded most Indians on grounds of birth or poverty. Learning in high schools was vigilantly checked by regular inspections and matriculation examinations. The control of textbooks was one of the measures by which the State maintained supervision over the vast body of public schools. The pedagogical content of secondary schools was prescribed by the British Crown; even colonial officials exercised the right to reject textbooks used in private schools, such as madrasahs (Bhatt \& Aggarwal, 1969). The schools were strict to follow learning exercises and schedules, or regulations directed by the British rulers.

Under the reforms of 1919-1921 the elementary education was made free within municipalities and rural unions and in Bangladesh the first steps towards universal primary education were taken through the Bengal primary education act 1930 (Memmi, 1957). A provincial department of education was established in 1930, and thus began the process of centralization and bureaucratization of education. Consequently, the enactment of 'The Bengal Education Code 1931' (The Bengal Education Code 1931) was a landmark legislation that created the 'District School Board' as the administrative body for primary and secondary education. A Central Advisory Board was established in 1935, for policy formulation in education recommended by the 'Hertz Committee-1927'. In 1945, a separate Education Department was established under the Central Government and its responsibilities were entrusted to a member of the Central Executive (Nurullah \& Naik, 1951). Though the British at that time took initiative to develop the educational backwardness of Indian sub-continent (Mann, 2004), but the education imparted by them did not develop practical skills or technical knowledge, rather emphasized classical, humanistic curricula in schools to perpetuate the aristocratic tastes and manners of the upper class to create exclusively dependent elite (Ilon, 2000; Mukerji, 1956; Seal, 1968). This elite class, who had job prospects and social upward mobility at certain level (Roy, 1993; Basu, 1934), provided clerical and administrative support to the colonial administration which encompassed areas of immense linguistic and cultural variety and became faithful customers to British goods (Chatterjee, 1994). But, the new elite became alienated from the masses of the people, who had no access to the new education system (Basu, 1952; Bhattacharya, 2005; Robb, 2002).

Economic and socio-religious mobility were the major hindrances for the poor in British India to enroll in schools. The caste allied socio-religious restrictions were imposed upon the poor to prevent them from achieving knowledge. The cost of education was another important factor that pushed away the poor from schools. The direct cost of schooling, expenditures such as books, fees, uniform, and so on, and indirect costs in terms of foregone earnings while child was at school were key economic factors for the poor. The poor could not overcome these hurdles in order to achieve knowledge. Instead of trying for the upliftment of the poor, the colonial government introduced the education policy based on the "filtration theory" (Bray, 1993). Nurullah and Naik (1951) also criticised the British for not having developed a truly national system of education; for failing to evolve a synthesis of eastern and western cultures; for neglecting indigenous education and for the absence of any overall plan or consistent drive to reach a predetermined goal.

\section{Secondary Education and Schools in Bangladesh during Pakistani Rule}

With the end of the British rule in 1947, the sub-continent was partitioned into two independent countries, India and Pakistan. Bangladesh became one of the provinces of Pakistan and was named as East Pakistan. There was a general awareness of the need to restructure the education system to meet the needs of the new nation. The country came into being as a result of an ideology based on the Islamic system of values and culture. Urdu was adopted as its national language and therefore became the medium of instruction in most of the public schools. The experiments with Urdu in education during that period were linguistically and philosophically defensible from a narrowly patriotic or nationalistic 
point of view. However, at the time of independence there was a considerable presence of missionary schools and colleges in which the medium of instruction was English.

The founding father of Pakistan, Mohammad Ali Jinnah made efforts to give a definite direction to education in Pakistan. Through the educational system he wanted to build up the character of the future generations. In the meantime, 'First Education Conference' was held in 1947 at Karachi, 27 November-1st December (GoP, 1947). This conference was convened to reassess the colonial education system and to restructure the existing educational system with due regard to ideological and literacy considerations. The second major area taken into consideration was the training and development of scientific and technical manpower. The third point on the agenda was to plan education in conformity with national genius and aspirations. In the Education Conference at Karachi Mohammad Ali Jinnah said, “...We have to build up the character of our future generations. We should try, by sound education, to instill into them the highest sense of honour, integrity, responsibility and selfless service to the nation. We have to see that they are fully qualified and equipped to play their part in the various branches of national life in a manner which will do honour to Pakistan." While commenting on the quality of education, he said, "Education does not merely mean academic education, and even that appears to be of a very poor type" (GoP, 1989). With this in mind successive policy makers made a number of policies. The plan was to build coherence between spiritual, social and vocational education and to promote democracy through universal primary education by making education free and compulsory, initially to class five and eventually to class eight. Madrasah education would be brought into the fold of formal school education. In addition to formal education at the elementary level, other areas for the promotion of Islamic education were taken into account in keeping with the ideology of the new independent state.

In 1949, Maulana Akram Khan Committee on education was established and in 1951, Second Education Congress was held at Karachi, 4-6 December (GoP, 1949; GoP, 1951). Following the reports of 'Akram Khan Committee' and 'Ataur Rahman Khan Commission 1957' the united front government wished for a universal single stream primary and secondary education system for all, based on scientific knowledge. In 1956, the constitution of Pakistan eventually recognized Bangla as one of the national languages. In the successive five-year plans and other national economic policy documents developed during the Pakistan period, the need of modern science education was also articulated but the impact of such policies was not felt in East Pakistan.

Newly formed Sharif Commission on education (1958) and the 'Curriculum committee for secondary education (classess vi-xii)' under military rule, also articulated in their report a need to shift the focus of school education away from rote memorization and to expand facilities for scientific and technological education (GoP, 1960). The Curriculum committee for secondary education (classess vi-xii) produced a report, a document of 647 pages, in the record time of three months. However, the new policy was an outcome of the political agenda of the government of that time. Its mandate was to evolve a national system of education that would reflect the spiritual, moral and cultural values of Independent Pakistan, and enable the system to meet the growing needs of the nation in the fields of agriculture, scientific and technological development. The objectives of this report for secondary education may be encapsulated as follows: "To develop, (a) a good worker (b) a good citizen (c) a good individual and (d) a good patriot." Such statements might seem unarguable, but they are more in the nature of pious sentiments than of implementable objectives. The difficulty lies in their general incommensurability. Thus, though the policy set aims and objectives relevant to the needs of new state, it failed to provide a clear-cut strategy to attain them. The absence of an implementation plan reduced the policy to mere words. The dictatorship of that time was struggling to gain political recognition and thought of creating short-term economic gains whereby a greater number of people could find jobs and GDP could increase. However, the 'Sharif Report' was comprehensive in its recommendations. They emphasized universal primary schooling, eradicating illiteracy and promoting the national language, among others. The committee also incorporated suggestions for a few basic changes in the administrative set-up, such as decentralizing the management of primary education, revamping the examination system, and envisaging a new management structure for technical education.

In 1959, breaking the traditional one stream secondary education, separate streams were introduced after Class-8, namely Arts, Science and Commerce. The East Pakistan Intermediate and Secondary Education Ordinance of 1961 spelt out the law regarding establishment of managing committees for secondary schools. Based on this ordinance, regulations were framed at various times on such matters as student fees, admission and registration, holding public examinations and terms of teachers' service. East Pakistan Secondary Education Board took charge of the affiliation and examination of secondary level institutions. This step was followed by the creation of a School Textbook Board in 1954. Later on, one Education Board was split into four on the principle of one Board for each administrative division of the country. These 4 Boards shared between them the responsibilities of granting recognition to the schools, supply of textbooks, inspection and above all holding two public examinations, one at the end of the tenth year of schooling (Secondary) and the other at the end of the twelfth year (Higher Secondary).

During that time, student movement (1962 -64) was created against the Sharif Commission with a demand of pro-people education policy and as a result, in 1964, the new 'Commission on student problems and welfare' was 
appointed headed by Justice Hamoodur Rahman (GoP, 1966; Bangla Pedia, 2005). But, with only a few exceptions, a liberal elite-based secondary education system with very little awareness of life in the countryside was in place. However, the commission report criticized a few elitist secondary educational institutions which did not fit in with principles of equality and social justice (GoP, 1966). The commission reported, "The idea of superior and inferior schools does not fit in with our socio economic pattern and principles of equality and social justice as enunciated by Islam which have been declared as the avowed policy of the state in the preamble of our Constitution" (GoP, 1966). Curle (1966) has pointed out that during the Ayub Khan regime (1958-1969), Pakistan's education system was elitist and there was no apathy towards educating the masses.

In 1969, General Yahya's government appointed a committee, with Air Marshal Nur Khan at its head, to overhaul the educational system. The rationale behind yet another educational policy was that education had failed to promote national cohesion, especially on account of East Pakistan separatist feelings which finally directed to the disintegration of Pakistan in 1971, and that it had not played its proper role in national development. There was a high rate of unemployment among the educated youth and academic standards were low. This policy visualized the promotion of a common set of cultural values based on the precepts of Islam. Creating a literate society and developing vocational and technical manpower was its focal point. The recommendations given for changing this vision into reality were to integrate Madrasahs into the normal school system and bring the latter in line with ideological demands, to integrate primary and middle schools with elementary schools, to undertake a massive program of adult education, to decentralize educational administration and to establish the University Grants Commission. This committee also recommended Urdu and Bangla, instead of English would be the medium of instruction in Pakistan by 1975 (GoP, 1969).

This policy clearly shows that education was used, once again, for political purposes. Therefore, the policy also put a brake on progress and made the country dependent leading to technological backwardness. The phenomenon of keeping education exclusive to some in Pakistan was also the legacy of colonial education. Middle class people are often skeptical of an educated mass people fearing loss of their monopoly in job market. Another issue, the sub-continent is predominantly rural and agrarian. Keeping this fact in view the Education Commission didn't give due consideration to its rural population. However, since its inception Pakistan's educational system has been unstable. The reasons for this can be attributed to lack of political will, language problems, frequent policy changes, conservative attitudes of religious leadership, poor financial resources, a weak structure and ignorance on the part of the masses. Effective leadership and a promising vision have been lost in a fog of clerical negativism compounded by bureaucratic and social indifference.

The 'Universal Declaration of Human Rights' (Article 26) of 1948 recognizes education as one of the 'Thirty Basic Human Rights' and stresses the need for education as a major driving force for economic and social development. Similarly the UNESCO Convention against Discrimination in Education, Article-4 (1960) implies free and compulsory primary and secondary education available and accessible to everyone and higher education equally accessible to everyone on the basis of individual capacity. But in Pakistan after independence, the leaders could not give education its due place in the first two constitutions, namely, those of 1956 and 1962. There was no definite time frame for making free and compulsory primary and secondary education available to the nation as its Fundamental Right. Therefore, a more coordinated and focused effort could bring the majority of population into the mainstream education. Whereas the Committee on Rural Education 1957 in India, recommended greater focus on agriculture education in secondary schools for better performance of the sector (Kaur, 2003), in Pakistan, school education remained a dream for the majority living in the rural areas of the country. However, in 1960's, one Boys' and one Girls' secondary school in each 'Mohukuma' (administrative region) were taken over by the Pakistani rulers as public schools.

\section{School Education and Schools in Bangladesh after Liberation}

Economic disparity, extraction of wealth and socio-political repression made East Pakistan very discontented. Starting from the language movement in the year 1952 to establish Bangla as a national language (Alam, 1991; Umar, 1970), the people of East Pakistan had struggled hard for democracy and autonomy, which turned into a war of liberation in 1971 (Zaheer, 1994). After a protracted nine months long war, Bangladesh finally achieved her independence. Bangladesh inherited, on Liberation in 1971, a literacy rate of 17.61 per cent of the population of all ages (GoB, 2004a).

The first Education Commission in Bangladesh appointed under Dr. Qudrat-e-Khuda submitted the report in 1974. The report emphasized on secular education at all level, future work-relevant technical and vocational education, improved assessment system, letter grading in the assessment of student performance in all stages of education and making primary education from grade 1 to 8 and secondary from grade 9 to 12 (GoB, 1974). The report firmly asserted that women's education should be such as to be of help to them in their domestic life, and stressed that subjects such as child-care, the nursing of the sick, preservation of health, food and nutrition must be included. It also suggested that girls should be channelled into 'vocations specially suitable to them', such as primary-school teaching, nursing and typing (Jalaluddin \& Chowdhury, 1997). 
An Advisory Committee was appointed in 1978 to have a fresh look at the issues and problems of education (Shahadat, 1999) which submitted an 'Interim Education Policy 1979' report on 8th February, 1979. The interim education policy document consisting of the recommendations of the National Education Advisory Council, headed by the State Ministry of Education, was hastily formulated as a new blue print for the education sector. The interim policy document put emphasis on increased literacy so that people could take part in the development of the country. The document established the current educational framework with secondary education consisting of three sub-stages; namely, junior secondary (3 years), secondary (2 years), and higher secondary ( 2 years). In addition, the document stipulated the following: "(a) terminal examination will be conducted by the District Education Authorities for all stages of secondary education; (b) vocational, technical, agricultural and medical education will be included and integrated into secondary and higher secondary education; (c) there will be provision of skills development in any technical subject at junior secondary and secondary levels." In regard to madrasah education, the 'Interim Education Policy' stipulated that it should be reorganized to ensure its equivalence to general education in such a way that the 'dakhil' level would correspond to secondary and 'alim' to higher secondary education (GoB, 1979; UNESCO, 2007). The Madrasah Education Ordinance was also issued in 1978 and in 1981, Govt. introduced, for the first time, service rules and salary subvention system for teachers and staffs of private secondary institutions. Before 1980 public sector contribution towards salary subvention to non- government educational institutions at secondary and higher secondary level was limited in the form of 'Dearness Allowance'. Initially teachers used to get $50 \%$ of their basic salary quarterly through district treasury. The office of the Director of Public Instruction (DPI) was upgraded as the Directorate of Secondary and Higher Education (DSHE) in 1981. In 1983 the government formed a cadre named BCS (General Education) and the government college teachers, public secondary school headmasters, district education officers came under the cadre service. Under the rule of Lt. Gen. Hossain Muhammed Ershad (1982-90), in 1983, the 'Enam committee' for administrative reconstruction made 14 subject-based teacher-posts in each government public school. But in the amended recruitment rules for teachers in 1989, all the posts were made 'Asst. teacher'. Teachers' associations demanded of upgrading the status of secondary school teachers as they were getting the status of class-III government employees.

Two military regimes i.e. Maj. Gen. Ziaur Rahman (1975-1981) and Lt. Gen. H.M. Ershad (1982-1990) changed Bangladeshi identity politics from a secular and ethnic "Bengali" identity to State-based and pseudo-Islamic 'Bangladeshi' identity to build political legitimacy and take Bangladesh out of Indian shadow. Education was used as a vehicle for promoting 'Bangladeshi' nationalism. The two regimes made constitutional changes to erase secularism by 'absolute trust and faith in Allah' and Islam as the 'State religion' in 1979 and 1988 respectively. Therefore, during General Ershard's rule and afterwards there has been unplanned mushrooming of Madrasahs/religious schools in Bangladesh. Religious education was used as a tool for attracting votes of religious people and to beat the secular opposition in electoral politics. The Ershad regime made Islamic studies compulsory up to the secondary level amid strong opposition from secular and left leaning parties (Gustavsson, 1991). The regime patronised Madrasah education from primary to higher secondary level with government recognition. Furthermore, like different political governments after liberation in 1971, 'Ershard Government' took the responsibility of secondary education by nationalising a good number of schools throughout the country.

Bangladesh was under military-led quasi democracy throughout 1975-1990. During 1980s, the reports of 'Mazid Khan Commission 1983' and 'Mofiz Commission 1988' on education were not widely disseminated and like many other reports of the past, were not formally adopted for implementation (Sahadath, 1999; GoB, 1988). Democratic practice has been in existence since 1990s and many changes and development took place at the secondary level of education system. At the beginning of 1990s many public schools were made double shift school, newly teaching posts were created and thus a significant change was made. Female students' stipend programme (FSP), increase of government subsidy in monthly pay order (MPO) and a new assessment system at SSC examination were also introduced in 1992. Raynor and Chowdhury (2004) claim that, "The stipend programme has brought about change. Adolescent girls are now visible in large numbers, going to and from school in rural areas- in itself a fundamental change. The female stipend programme (FSP) offers an allowance to encourage families to send girls to school, and to help to meet the costs of education."

During mid 1990s, the secondary school curriculum was revised, approximately 150,000 teachers received short-term training in the new curriculum; ten teacher-training colleges were upgraded and five new higher teacher training institutes were established. At the end of 1990s, 'Shamsul Haque Education Commission 1997' was formed. Correspondingly, in 2001 and 2003 two other commissions 'Abdul Bari commission 2001' and Moniruzzaman Miah Education Commission 2003' were formed. The later submitted its report in 2004 and advocated for a single-track secondary education system, wider access to education in rural areas, narrowing down teacher-student ratio, upgrading teacher qualifications, reforming the curricular and teaching methods, and improving the assessment and examination systems at secondary level (GoB, 2004b). In different phases the amount of public sector contribution towards salary subvention to non- government educational institutions at secondary and higher secondary level was increased to $60 \%$, 
$70 \%$ and $80 \%$ and finally up to $90 \%$ in 2001 . The remaining $10 \%$ was given by the institutions. Teachers and staffs were also given $25 \%$ and $50 \%$ of their basic salary as festival allowance and limited house rent respectively. Recently Government is giving $100 \%$ of salary subvention to the teachers of non- government educational institutions and the disbursement is made monthly through teacher's personal bank account.

Nowadays, the major focus of Bangladesh education policy at school level switched from "quantity" to "quality". Reforms are being implemented in school managing committee (SMC), retirement and service benefit of non-government teachers, teacher training, information technology and computer education, secondary curriculum, school-based assessment system (SBA) and English language teaching (GoB, 2005; World Bank, 2005). 'Quality Assurance' is now pursuing to help evaluating schools' performance using a set of indicators (World Bank, 2006). The Sixth Five Year Plan (2003-2008), issued by the Planning Commission, presents the following targets in regard to secondary education: (a) increasing participation in different levels and types of education, such as lower secondary, secondary, and higher secondary levels including madrasah education; (b) increasing participation of girls through stipend programmes in all levels of secondary education; and (c) increasing quality of secondary education through in-service training of teachers (UNESCO, 2007). Despite these initiatives, Bangladesh faces new challenges and demands in education sector and secondary education system is still facing problems to deliver quality education (Ahmad, 2005).

Even though there have been seven education commissions formed till date but Bangladesh has not been able to have a realistic education policy after 38 years of its independence. Successive governments in Bangladesh, whether for political motives or real attempts at getting it right, have always advanced legitimate explanations for embarking upon one reform program or the other. Over the years, emphasis is given on quantity by setting up unnecessary secondary education institutions to satisfy politicians and their constituencies (GoB, 2005). These schools don't have adequate facilities, qualified teachers and above all competent educational administrators (Begum \& Bhuyan, 2005). So, secondary education in Bangladesh ignores, in a thousand ways, the rules of integral, transformational healthy educational development. Evidently the ineffectual manner by which the policies were implemented ensured that educational panning was social-demand oriented rather than manpower oriented (Mahmud, 2003; Sen, 2002). The secondary graduates, therefore, suffer with no marketable skills to sell to prospective employers and millions of these graduates roaming the city and town streets (Ilon, 2000; GoB, 2005).

\section{Proposed Education Policy 2009}

The present Awami League (AL) government having a decisive victory in the recent national elections is designing another new national education policy. The government formed a sixteen member committee to update the National Education Policy 2000 which was headed by National Professor Kabir Chowdhury (The Daily Prothom Alo, 2009). The proposed new education policy is formulated in the light of the 'Qudrat-e-Khuda Commission' report of 1974 and 'Shamsul Huq Education Commission Report' of 1997. This is indeed timely, especially in a globalising world in which other countries, such as China, India have pushed themselves into the 21 st century by vigorously engaging in knowledge revolution and human resource development.

The final draft of the National Education Policy 2009 was formally submitted to the Prime Minister on 7 September, 2009. The salient features of the recommendations of the committee include revising the stages of under-graduate education from three to two, the mandatory inclusion of certain compulsory subjects under all streams of education, making education more need-based and formation of a permanent education commission (The Financial Express, 2009). The Policy paper recommends extending compulsory primary schooling to eight years. Final primary level exams will be held at the end of Class 8 and secondary school scholarships will be awarded based on the results. The new policy also recommends that secondary level studies will extend over four academic years, Classes 9-12, and the government scholarship exams will be taken at the end of Class 10, instead of SSC exams. Final secondary level exams will be held at the end of Class 12. Some fundamental subjects including Bangla, moral education, Bangladesh studies, mathematics, natural environment, social studies, IT and science will be made compulsory in different streams of primary and secondary level curriculum. The policy also calls for some form of technical and vocational education to be introduced at all secondary level institutions. Accordingly, madrasah education will be restructured by including information technology and vocational training among compulsory subjects. It has also recommended formation of a non-government teachers' commission. Such broad proposals are to be welcomed, specially the one requiring all students to be taught certain compulsory subjects such as science and mathematics at the primary and secondary levels (The Financial Express, 2009).

Education has been proving to be the centre point of realizing national aspirations in all fields. Therefore, Andaleeb (2009) stresses for various stakeholders' commitment in the education sector as very important determinant of any accomplishment. He also claims that the education sector is financially challenged. The allocation of cash to education sector in Bangladesh, which is roughly $2.7 \%$ of GDP, must be increased to a large extent. In other countries the comparative numbers are roughly; India 3.2\%, Thailand 4.2\%, Malaysia 6.2\%, UK 5.6\% and USA 5.3\% (Andaleeb, 
2009). However, the government should also look into the earlier education policy documents and translate the recommendations into action. Girl's right to education, inclusive education, indigenous children and their right to learn own languages should be well documented in the policy proposals. Moreover, it must also address environmental issues, health and nutrition, character education, conflict resolution and participation of local government in the whole education system. It is important to consider whether the government is institutionally prepared enough for the proposed change. There is much to be improved upon, and strengthened particularly in areas of capacity building and availability of competent teachers to operationalise the new policy as effectively as possible. It is also imperative to set up effective, supportive infrastructures, particularly in thrust areas, in order to make education truly useful for the economy.

Designing an education policy is a tough task. Perhaps a little more time should be budgeted to think through the vital issues. In no way, the scope for incorporation of commendable suggestions by all concerned quarters should be excluded before the policy gets the final approval for implementation. Therefore, the proposed policy is going through the usual phases of some scrutiny at the expert level. The policy also will require a closer and careful examination and have to be mandated by the country's parliament. The education minister hopes that after finalizing the policy, its full-fledged implementation will begin from early in the year 2010 (The Financial Express, 2009).

\section{Conclusion}

The education system of Bangladesh is continually undergoing reforms in order to meet the current and future needs and challenges of the socio-economic developments of the country. In that course of change, secondary education has achieved a number of positive developments. Bangladesh has made significant progress in providing more young people with access to secondary education, increased enrolment, especially for girls; increased number of schools and teachers, reduction of gender inequality in education, revision of curriculum, etc. Even so, in spite of all remarkable achievements, declining quality in secondary education system, which is reflected in public examination results, remains a major concern. Bangladesh government fully recognizes the urgent need to improve the quality of education alongside its efforts for creating equitable access to secondary education. The issues of access, equity and quality however being intertwined have to be looked at in totality in an integrated manner, and the strategies to address them must also look at the key areas simultaneously, not in a piecemeal fashion. More investment in this sector is needed although there are a number of inadequacies, hindrances and a scarcity of financial resources. However, what is of interest to all stakeholders is the identification of factors or variables that enhance learning in all schools, irrespective of the background of the children that attend them and are generalisable to all schools.

\section{References}

Ahmad, Q. K. (2005). Poverty and education with particular reference to Bangladesh. Dhaka: Campaign for Popular Education (CAMPE).

Alam, S. (1991). Language as political articulation: East Bengal in 1952. Journal of Contemporary Asia, 21 (4), 469-487.

Ali, M. A. (1986). Shikhar Songkhipto Itihash (in Bangla) Dhaka: Bangla Academy.

Andaleeb, S. S. (2009). Bangladesh's new education policy must consider 7 C's. [Online] Available at http://southasia.oneworld.net/opinioncomment/bangladeshs-new-education-policy-must-consider-7cs

Bangladesh Bureau of Educational Information and Statistics (BANBEIS). (2006). National Education Survey (Post-Primary) -2005: Final Report. Dhaka: Ministry of Education.

Bangla Pedia. (2005). National encyclopedia of Bangladesh. [Online] Available: http://www. banglapedia.org/ (Accessed on December 20, 2008).

Basu, A.N. (1952). Indian Education in Parliamentary Papers, Part I. Bombay: Asia Publishing.

Basu, B.D. (1934). History of Education in India under the Rule of the East India Company. Calcutta: Modern Review Office.

The Bengal Education Code 1931. Calcutta: The Director of Public Instruction, Bengal.

Begum, A. \& Bhuyan, H. R. (May 2005). Education for Poverty Reduction: Achievements and Challenges. Paper Presented at the Seminar on National Budget for 2005-06 and PRSP on May 29, 2005. Dhaka: Bangladesh Institute of Development Studies (BIDS).

Bhatt, B.D. \& Aggarwal J.C. (1969). Educational Documents in India 1813-1968. New Delhi: Arya Book Depot.

Bhattacharya, T. (2005). The Sentinels of Culture: Class, Education and the Colonial Intellectual in Bengal (1848-85). New Delhi: Oxford University Press.

Bray, M. (1993). Education and the Vestiges of Colonialism: Self-Determination, Neo-Colonialism and Dependency in the South Pacific. Comparative Education, 29(3), 333-348. 
Case, A. (2006). The Primacy of Education. In A. Banerjee, R. Benabou \& D. Mookherjee (Eds,), Understanding Poverty (pp 269-284) Oxford University Press.

Chanana, K. (1994). Social change or social reform: Women, education and family in preindependence India. In C. C. Mukhopadhyay and S. Seymour (Eds.), (pp 35-58). Women, Education and Family Structure in India. Boulder, CO: Westview Press.

Chatterjee, K. K. (1976). English education in India: issues and opinions. New Delhi: The Macmillan Company of India Ltd.

Chatterjee, P. (1994). The Nation and Its Fragments: Colonial and Postcolonial Histories. Princeton: Princton University Press.

Curle, A. (1966). Planning for education in Pakistan: A personal case study. Cambridge: Harvard University Press.

Ghosh, S. C. (1993). English in Taste, in Opinions, in words and intellect: Indoctrinating the Indian through textbook, curriculum, and education. In J.A. Mangan (Ed), The imperial curriculum: Racial images and education in British colonial experience (pp 175-193). London and New York: Routledge.

Government of Bangladesh (GoB). (2004a). Bangladesh Moves Ahead. Dhaka: Ministry of Education.

Government of Bangladesh (GoB). (2005). Education policy. Dhaka: Ministry of Education. Available: $<$ http://www.moedu.gov.bd $>$ (Accessed on April 14, 2008).

Government of Bangladesh (GoB). (1972). Constitution of the Republic of Bangladesh. [Online] Available: (www.bangladeshgov.org/pmo/constitution/consti2.). (Accessed on February 20, 2009).

Government of Bangladesh (GoB). (1979). Interim Education Policy 1979. Dhaka: Ministry of Education.

Government of Bangladesh (GoB). (1988). Bangladesh national education report 1988. Dhaka: Ministry of Education.

Government of Bangladesh (GoB). (2004b). National Education Commission Report 2003. Dhaka: Ministry of Education.

Government of Pakistan (GoP). (1947). Pakistan Educational Conference: Proceedings of the meeting (27 November-1 December 1947). Lahore. Feroze printing works.

Government of Pakistan (GoP). (1949). Proceedings of the meetings of advisory board of education for Pakistan. Karachi. Education division.

Government of Pakistan (GoP). (1989). Quaid-I-Azam Muhammad Ali Jinnah, speeches and statements, 1947-48. Islamabad: Ministry of Information \& Broadcasting, Directorate of Films \& Publications Islamabad.

Government of Pakistan (GoP). (1951). Educational Conference 1951. Proceedings of the Educational Conference held at Karachi on 4th and 5th December, 1951. Ministry of Education, Islamabad Educational Division: Manager of Publications, Karachi.

Government of Pakistan (GoP). (1960). Report of the commission on national education (CNE). Karachi: Ministry of Education.

Government of Pakistan (GoP). (1966). Report of the commission on student problems and welfare (RCSP): Summary of the important observations and recommendations. Karachi: Ministry of Education.

Government of Pakistan (GoP). (1969). Proposals for a new educational policy (PNEP). Islamabad: Ministry of Education and Scientific Research.

Government of People's Republic of Bangladesh (GoB). (1974). Bangladesh Education Commission Report 1974. Dhaka: Ministry of Education.

Gustavsson, S. (1991). Primary education in Bangladesh: Review, analysis and recommendations. Stockholm: SIDA.

Ilon, L. (2000). Colonial secondary education in a global age: Economic distortions in Bangladesh. Asia pacific education review, 1(1), 91-99.

Islam, S. (1992). History of Bangladesh (1704-1971). Dhaka: Asiatic Society of Bangladesh.

Jalaluddin, A. \& Chowdhury, M.R. (1997) Getting Started: universalising quality primary education in Bangladesh. Dhaka: University Press

Kaur. K. (2003). Higher Education in India (1781-2003). New Delhi: University Grants Commission of India.

Kumar, K. (1991). A Political Agenda of Education: A Study of Colonist and Nationalist Ideas. New Delhi: Sage.

Mahmud, S. (2003). Female secondary stipend project in Bangladesh: a critical assessment. Dhaka: Bangladesh Institute of Development Studies (BIDS). 
Mann, M. (2004). Torchbearers upon the path of progress: Britain's ideology of a moral and material progress in India. In H. Fischer-Tiné and M. Mann (Eds.), Colonialism as civilizing mission: Cultural ideology in British India (pp. 1-26). London: Anthem Press.

McGrath, S. (1999). Education, development and assistance: the challenge of the new millennium. In, K. King, L. Buchert, (Eds.), Changing international aid to education; Global patterns and national contexts (pp. 68-90). Paris: UNESCO.

McLeod, J. (2002). The history of India. Westport, CT: Greenwood Press.

Memmi, A. (1957). The colonizer and the colonized. Boston: Bacon Press.

Mominullah, M. (1982). Shikhanitir Mulkotha (in Bangla). Dhaka: Mita Prokashon.

Mukerji, S.N. (1956). Higher education and rural India. Baroda: Acharya Book Depot.

Mukerji, S.N. (1957). History of education in India: Modern Period. Baroda: Acharya Book Depot.

Mulford, B. (2002). Secondary education for a better future: Trends, challenges and priorities. Sultanate of Oman, Muscat: Ministry of education.

Nurullah, S. \& Naik, J.P. (1951). A History of Education in India (1800-1947). Calcutta. Macmillan \& Co Ltd.

Nurullah, S. \& Naik, J.P. (1962). A student history of education in India (1860- 1965). New Delhi: Macmillan \& Co Ltd.

New age. (2008). Tuesday, January 1.

Raynor, J. \& Chowdhury, R. A. (2004). A national assessment of girls'secondary stipend programmes in Bangladesh. Dhaka: DfID.

Robb, P. (2002). A history of India. New York: Palgrave.

Roy, M. (1993). The Englishing of India: Class Formation and Social Privilege. Social Scientist, 21(5-6 May-June), 36-62.

Seal, A. (1968). The Emergence of Indian Nationalism: Competition and Collaboration in the Later Nineteenth Century. Cambridge: Cambridge University Press.

Sen, G. C. (2002). Quality education for poverty reduction in Bangladesh. Keynote paper presented at the workshop organized by the MoE on June 18, 2002. Dhaka.

Shahadat H. C. (1999). NFE interventions in Bangladesh. Dhaka. Directorate of Non-formal Education.

Sinha, S.P. (1978). English in India. Patna: Janaki Prakashan.

Sultana, R. \& Sultana, Z. (2005). Information, projection and recommendations on the organ gram of personnel in 9 Regional Office of Deputy-Director, 64 District Education Offices and 317 public secondary schools in Bangladesh. Dhaka: Directorate of Secondary and Higher Education (DSHE).

The Daily Prothom Alo. (2009). Thursday. April 9.

The Daily Star. (2005). Wednesday. January 19.

The Daily Star. (2008). Friday. June 27.

The Financial Express. (2009). Saturday. September 5.

Umar, B. (1970). Purba Banglar Bhasha Ondolan-o-Tatkalin Rajniti [in Bangla]. (Language movement of East Bengal and contemporary politics of the time). Dhaka: Mowla Brothers.

UNESCO. (2000). Dakar Framework for Action, Education for All: Meeting our Collective Commitments. France: World Education Forum.

UNESCO. (2007). Secondary education regional information base: country profile-Bangladesh. Bangkok: UNESCO. Viswanathan, G. (1989). Masks of conquest: Literary study and British rule in India. New York: Columbia University Press.

World Bank. (2005). Simplified Implementation Completion Report: The People's Republic of Bangladesh, Programmatic Education Sector Adjustment Credit. Dhaka: World Bank.

World Bank. (2006). Program document for a proposed second programmatic education sector development support credit in the amount of sdr 69.1 million (US\$100 million equivalent) to the People's Rebublic of Bangladesh. Report 35015-BD.Washington, DC: World Bank.

Zaheer, H. (1994). The Separation of East Pakistan. Karachi: Oxford University Press. 


\section{Appendix: A}

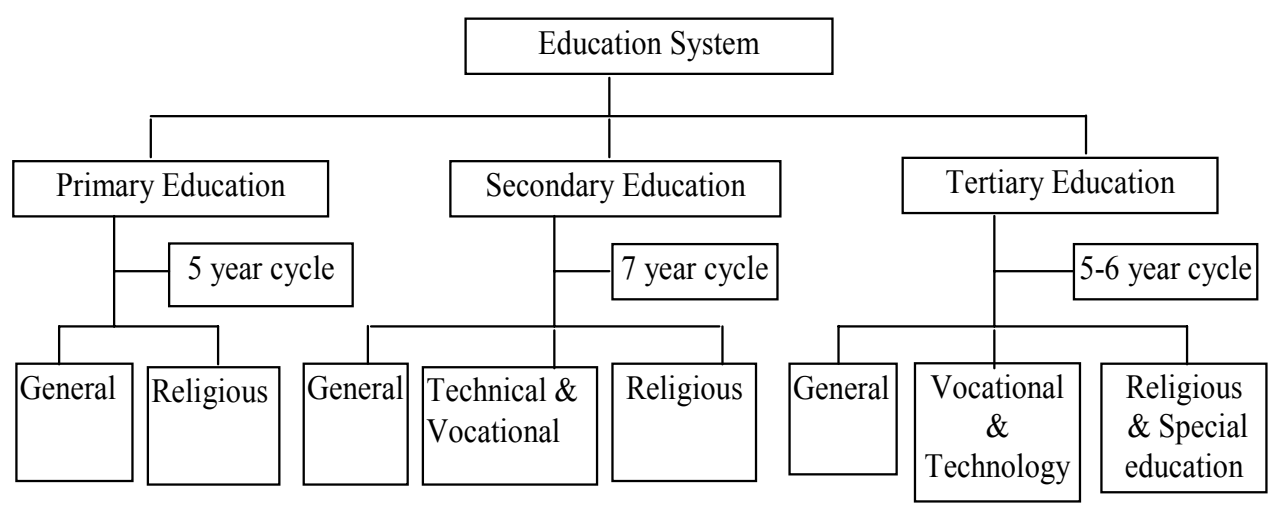

Figure1. Different Streams of Education System in Bangladesh

\section{Appendix: B}

Table1. Number of Institutions, Teachers and Students by Stream of Education in Bangladesh

\begin{tabular}{|l|c|c|c|c|c|c|}
\hline Type of school based on streams & \multicolumn{2}{|c|}{ No. of Institutions } & \multicolumn{2}{|c|}{ No. of Teachers } & \multicolumn{2}{c|}{ Enrolment } \\
\hline & Total & Female & Total & Female & Total & Female \\
\hline Total Secondary Education (General) & 18500 & 3708 & 232929 & 46983 & 7398552 & 3868014 \\
\hline Public secondary school & 317 & 147 & 7434 & 2333 & 221887 & 106316 \\
\hline Madrasah -Dakhil & 6685 & 1017 & 98123 & 9908 & 2236025 & 1170220 \\
\hline Madrasah - Alim & 1315 & 91 & 25634 & 1803 & 550813 & 253207 \\
\hline Total Technical/ vocational Education & 2728 & 267 & 18185 & 3208 & 241336 & 62562 \\
\hline
\end{tabular}

Source: BANBEIS (2006)

Table 2. Number of Public Secondary High Schools by Region in Bangladesh

\begin{tabular}{|l|c|c|c|}
\hline Region & Boys' school & Girls' schools & Total schools \\
\hline Dhaka & 33 & 25 & 58 \\
\hline Mymensing & 17 & 14 & 31 \\
\hline Rajshahi & 20 & 17 & 37 \\
\hline Chittagong & 35 & 19 & 54 \\
\hline Comilla & 13 & 10 & 23 \\
\hline Rangpur & 16 & 22 & 38 \\
\hline Khulna & 15 & 21 & 36 \\
\hline Barisal & 10 & 10 & 20 \\
\hline Sylhet & 12 & 08 & 20 \\
\hline Total & 170 & 147 & 317 \\
\hline
\end{tabular}

Source: Sultana \& Sultana (2005) 